Reviu Akuntansi dan Bisnis Indonesia, Vol. 1 No. 2, Hlm: 144-151, Desember 2017

Website: http://journal.umy.ac.id/index.php/rab

\title{
Pengaruh Partisipasi Anggaran, Kejelasan Sasaran Anggaran, Budaya Organisasi, Reputasi dan Etika Terhadap Senjangan Anggaran (Studi Empiris pada SKPD Kabupaten Bantul)
}

\author{
Mellyanda Febrina Audia; Bambang Jatmiko \\ Program Studi Akuntansi Univeritas Muhammadiyah Yogyakarta.
}

I N F O A R T I K E L

\section{Kata Kunci:}

Partisipasi Anggaran,

Kejelasan Sasaran Anggaran,

Budaya Organisasi, Reputasi,

Etika dan Senjangan

Anggaran pada Satuan Kerja

Perangkat Daerah

Jenis Artikel:

Penelitian Empiris

\section{Correspondence:}

bambang_jatmiko65@yahoo.com

\author{
A B S T R A K
}

Penelitian ini bertujuan untuk mengetahui dampak partisipasi anggaran, kejelasan sasaran anggaran, budaya organisasi, reputasi dan etika terhadap senjangan anggaran pada satuan kerja perangkat daerah Kabupaten Bantul. Penelitian ini menggunakan metode penelitian survey. Teknik pengambilan sampel yang digunakan yaitu purposive sampling dengan adanya kriteria tertentu. Sampel dalam penelitian ini adalah kepala dinas/badan, kepala sub-bidang dan kepala sub-bagian yang bekerja di SKPD Kabupaten Bantul. Jenis data yang digunakan dalam penelitian ini yaitu data primer. Teknik pengumpulan data menggunakan kuesioner. Kuesioner yang dapat dianalisis sebanyak 80 kuesioner dari 100 kuesioner yang dibagikan. Pengujian hipotesis dalam penelitian ini menggunakan uji regresi berganda dengan uji $t$, uji $\mathbf{F}$ dan koefisien determinasi. Data yang terkumpul terlebih dahulu dianalisis dengan pengujian kualitas instrumen, uji asumsi klasik dan pengujian hipotesis dengan menggunakan alat uji SPSS versi 23 . Hasil penelitian ini menunjukkan bahwa partisipasi anggaran, kejelasan sasaran anggaran dan reputasi berpengaruh positif signifikan terhadap senjangan anggaran pada satuan kerja perangkat daerah. Namun, budaya organisasi dan etika tidak berpengaruh terhadap senjangan anggaran disatuan kerja perangkat daerah.

(C) 2019 RAB. Published by Universitas Muhammadiyah Yogyakarta

\section{PENDAHULUAN}

Berlakunya UU No. 32 Tahun 2004 tentang pemerintah daerah, memberikan perubahan penyerahan wewenang dari pemerintah pusat kepada pemerintah daerah untuk mengurus sendiri urusan pemerintahan dan kepentingan masyarakatnya. Penyerahan wewenang yang diberikan pemerintah pusat disebut dengan desentralisasi. Sumber daya yang dibutuhkan dalam pelaksanaan desentralisasi dicantumkan dalam Anggaran Pendapatan dan Belanja Daerah (APBD).

Anggaran merupakan rencana organisasi yang dituliskan dalam ukuran finansial, disusun dan digunakan dengan jangka waktu yang telah ditentukan. Setiap organisasi pemerintahan daerah dalam melakukan proses penganggaran diatur dalam PP No. 58 Tahun 2005 tentang pengelolaan keuangan daerah. Pengelolaan keuangan daerah yang berlaku Dalam Negeri ditetapkan peraturan Menteri Dalam Negeri No. 59 Tahun 2007 tentang pedoman pengelolaan keuangan daerah. Dalam melakukan proses penyusunan anggaran memungkinkan penyimpanga dapat mudah terjadi. Salah 
satu penyimpangan yang terjadi yaitu timbulnya senjangan anggaran. Senjangan anggaran adalah suatu perbedaan antara realisasi anggaran yang dihasilkan dengan perkiraan anggaran yang ditetapkan. Senjangan anggaran terjadi ketika para penyusun anggaran membuat pengeluaran lebih besar dari yang semestinya dan membuat pendapatan lebih rendah agar dapat mencapai target anggaran dengan lebih mudah (Harvey, 2015).

Pemerintah Kabupaten Bantul dalam melakukan proses penyusunan anggaran banyak melibatkan pihak pemerintah, legislatif dan masyarakat. APBD Kabupaten Bantul tahun anggaran 2011-2015 dapat dilihat pada tabel berikut:

Tabel 1 Realisasi APBD Kabupaten Bantul

Tahun Anggaran 2011-2015 (dalam Rupiah)

\begin{tabular}{lcccc}
\hline Tahun & $\begin{array}{c}\text { Anggaran } \\
\text { Pendapatan } \\
\text { Daerah }\end{array}$ & $\begin{array}{c}\text { Realisasi } \\
\text { Pendapatan } \\
\text { Daerah }\end{array}$ & $\begin{array}{c}\text { Anggaran Belanja } \\
\text { Daerah }\end{array}$ & $\begin{array}{c}\text { Realisasi Belanja } \\
\text { Daerah }\end{array}$ \\
\hline 2011 & 1.165 .047 .061 .158 & 1.180 .550 .742 .432 & 1.191 .039 .577 .220 & 1.151 .935 .591 .328 \\
2012 & 1.302 .131 .101 .144 & 1.337 .566 .093 .259 & 1.345 .680 .130 .605 & 1.282 .878 .383 .296 \\
2013 & 1.503 .865 .465 .664 & 1.522 .294 .390 .754 & 1.570 .168 .261 .924 & 1.387 .719 .170 .740 \\
2014 & 1.733 .247 .144 .497 & 1.813 .917 .142 .695 & 1.901 .335 .826 .511 & 1.700 .351 .278 .810 \\
2015 & 1.914 .059 .443 .086 & 1.951 .173 .970 .361 & 2.179 .257 .337 .075 & 1.933 .302 .495 .457 \\
\hline
\end{tabular}

Sumber: LAKIP Kabupaten Bantul Tahun 2011-2015

Tabel 1 mencerminkan adanya senjangan anggaran. Dapat diperhatikan dari anggaran pendapatan daerah dengan realisasinya, dan anggaran belanja daerah dengan realisasinya. Jika dilihat anggaran pendapatan daerah selalu memiliki angka yang lebih kecil dibandingkan dengan realisasinya. Kemudian dilihat dari anggaran belanja daerah selalu memiliki angka yang lebih besar dibandingkan dengan realisasinya. Sehingga, adanya perbedaan selisih antara realisasi anggaran yang dibutuhkan dengan estimasi anggaran yang dibuat dikatakan sebagai senjangan anggaran.

Berdasarkan latar belakang diatas dan adanya senjangan anggaran yang masih terjadi disatuan kerja perangkat daerah Kabupaten Bantul, peneliti bertujuan untuk menguji dan menganalisis apakah partisipasi anggaran, kejelasan sasaran anggaran, budaya organisasi, reputasi dan etika berpengaruh terhadap senjangan anggaran pada satuan kerja perangkat daerah.

\section{TINJAUAN LITERATUR DAN PERUMUSAN HIPOTESIS}

\section{Teori Stewardship (Stewardship Theory)}

Nosihana dan Yaya (2016) menyatakan bahwa teori stewardship merupakan situasi yang menggambarkan keadaan dimana manajemen lebih termotivasi pada tujuan sasaran utama mereka yaitu kepentingan organisasi dibandingkan dengan tujuan-tujuan individu. Hubungan antara steward dan prinsipal terjadi dimana pemerintah daerah (eksekutif) bertindak sebagai steward yang bertugas untuk mengelola sumber daya dan rakyat yang bertindak sebagai prinsipal selaku pemilik sumber daya. Antara eksekutif dan prinsipal terjalin kesepakatan berdasarkan kepercayaan.

\section{Pengaruh Partisipasi Anggaran terhadap Senjangan Anggaran}

Partisipasi dalam penyusunan anggaran merupakan suatu proses dimana atasan maupun bawahan memberikan pengaruhnya dalam menentukan target anggaran (Putri dan Pradnyantha, 2014). Tingginya partisipasi bawahan dalam penyusunan anggaran, akan memicu timbulnya senjangan anggaran yang tinggi. Bawahan akan merasa bertanggung jawab atas anggaran yang telah disusun. Akibatnya bawahan merasa tertekan dan berusaha untuk mencapai target anggaran tersebut dengan lebih mudah, sehingga membuat senjangan anggaran. 
Penelitian yang dilakukan Putri dan Pradnyantha (2014) menunjukkan bahwa partisipasi anggaran berpengaruh signifikan positif terhadap senjangan anggaran pada satuan kerja perangkat daerah. Berdasarkan uraian diatas, maka peneliti menarik sebuah hipotesis yaitu:

\section{$\boldsymbol{H}_{\boldsymbol{I}} \quad$ : Partisipasi anggaran berpengaruh positif terhadap senjangan anggaran}

\section{Pengaruh Kejelasan Sasaran Anggaran terhadap Senjangan Anggaran}

Menurut Priyanti (2013) kejelasan sasaran anggaran merupakan sejauh manaanggaran yang telah ditetapkan dengan jelas dan tepat dengan tujuan anggaran tersebut mudah untuk dimengerti oleh orang yang bertanggung jawab dalam menyusun dan melaksanakan anggaran. Dalam penyusunan anggaran, para penyusun anggaran harus membuat suatu anggaran yang jelas dan spesifik agar anggaran tersebut dapat menjadi lebih terarah. Adanya sasaran anggaran yang jelas akan memberikan kemudahan bagi individu untuk menyusun target-target anggaran. Dimana targettaget anggaran anggaran akan disusun sesuai dengan sasaran yang ingin dicapai oleh organisasi. Sehingga, semakin jelasnya sasaran anggaran didalam organisasi maka kemungkinan terjadinya senjangan anggaran akan semakin menurun.

Penelitian yang dilakukan Cika dan Asri (2014) menunjukkan kejelasan sasaran anggaran berpengaruh negatif terhadap senjangan anggaran pada satuan kerja perangkat daerah. Berdasarkan uraian diatas, maka peneliti menarik sebuah hipotesis yaitu:

\section{$\boldsymbol{H}_{2} \quad$ : Kejelasan sasaran anggaran berpengaruh negatif terhadap senjangan anggaran.}

\section{Pengaruh Budaya Organisasi terhadap Senjangan Anggaran}

Menurut Halim (2009) budaya organisasi adalah keyakinan, nilai, norma, dan sikap orangorang organisasi dalam berperilaku atau bertindak. Budaya organisasi dapat mempengaruhi cara bekerja dan perilaku anggota didalam organisasi termasuk dalam proses penyusunan anggaran Adanya budaya yang kuat didalam organisasi memotivasi anggota untuk bekerja agar tujuan organisasi dapat tercapai secara efektif, sehingga anggota organisasi akan terlibat penuh dalam mencapai target anggaran dengan menyusun anggaran sesuai apa adanya tanpa ada tujuan serta maksud yang lain. Kuatnya budaya yang tertanam didalam diri anggota organisasi dapat mengurangi terjadinyan senjangan anggaran.

Penelitian yang dilakukan oleh Ramadina (2013) menunjukkan budaya organisasi berpengaruh negatif terhadap senjangan anggaran. Berdasarkan uraian diatas, maka peneliti menarik sebuah hipotesis yaitu:

$\boldsymbol{H}_{3} \quad$ : Budaya organisasi berpengaruh negatif terhadap senjangan anggaran.

\section{Pengaruh Reputasi terhadap Senjangan Anggaran}

Reputasi merupakan nama baik yang dimiliki seseorang karena telah melakukan hal-hal yang positif dan telah melaksanakan tugas dengan baik. Tingginya reputasi yang dimiliki oleh seseorang, maka akan semakin tinggi keinginan untuk melakukan kesenjangan anggaran. Reputasi yang tinggi dapat menyebabkan seseorang untuk selalu ingin menjaga kinerjanya tetap terlihat baik agar mendapatkan penilaian yang baik.

Penelitian yang dilakukan Putri dan Pradnyantha (2014) menunjukkan bahwa reputasi berpengaruh signifikan positif terhadap senjangan anggaran pada satuan kerja perangkat daerah. Berdasarkan uraian diatas, maka peneliti menarik sebuah hipotesis yaitu: 
$\boldsymbol{H}_{4} \quad$ : Reputasi berpengaruh positif terhadap senjangan anggaran.

\section{Pengaruh Etika terhadap Senjangan Anggaran}

Etika merupakan suatu nilai dan norma moral yang dijadikan individu atau sekelompok orang sebagai pegangan untuk mengatur tingkah lakunya dengan melakukan perbuatan yang baik dan menghindari perilaku buruk. Seseorang yang memiliki etika yang baik akan mengurangi terjadinya senjangan anggaran, sebab mereka akan memandang senjangan anggaran sebagai sesuatu hal tidak baik untuk dilakukan dalam proses penyusunan anggaran karena hanya menguntungkan salah satu pihak dan dapat merugikan masyarakat dan Negara.

Penelitian yang dilakukan oleh Putri dan Pradnyantha (2014) menunjukkan etika berpengaruh negatif terhadap senjangan anggaran pada satuan kerja perangkat daerah. Berdasarkan uraian diatas, maka peneliti menarik sebuah hipotesis yaitu:

$\boldsymbol{H}_{s} \quad$ : Etika berpengaruh negatif terhadap senjangan anggaran.

\section{METODE PENELITIAN}

Obyek penelitian berupa lokasi atau tempat pelaksanaan penelitian. Penelitian ini dilaksanakan di Satuan Kerja Perangkat Daerah Kabupaten Bantul. Subyek penelitian terdiri dari populasi dan sampel yang sesuai dengan penelitian yang akan dilakukan. Populasi dalam penelitian ini adalah Satuan Kerja Perangkat Daerah (SKPD) Kabupaten Bantul yang terdiri dari 18 Dinas dan 4 Badan. Sampel yang diambil dari populasi dalam penelitian ini adalah pegawai SKPD yang terdiri dari kepala dinas, kepala badan, kepala sub-bagian dan kepala sub-bidang di Kabupaten Bantul. Jenis data yang digunakan dalam penelitian ini adalah data primer. Data ini diperoleh secara langsung dari Satuan Kerja Perangkat Daerah Kabupaten Bantul. Teknik pengumpulan data dalam penelitian ini menggunakan kuesioner. Kuesioner yang diberikan merupakan kuesioner secara langsung yaitu responden mengisi sendiri jawaban pertanyaan dari kuesioner yang diajukan mengenai partisipasi anggaran, kejelasan sasaran anggaran, budaya organisasi, reputasi, etika dan senjangan anggaran pada satuan kerja perangkat daerah Kabupaten Bantul.

\section{HASIL DAN PEMBAHASAN}

\section{Gambaran Umum Obyek/Subyek Penelitian}

Kabupaten Bantul merupakan salah satu kabupaten yang terletak di wilayah Provinsi Daerah Istimewa Yogyakarta, yaitu selain Kabupaten Sleman, Kabupaten Kulon Progo, Kabupaten Gunung Kidul dan Kota Yogyakarta. Secara geografis Kabupaten Bantul terletak diantara 07 44'04” $08^{\circ} 00^{\prime} 27^{\prime}$ lintang selatan dan $110^{\circ} 12^{\prime} 34^{\prime \prime}-110^{\circ} 31^{\prime} 08^{\prime \prime}$ bujur timur.

Teknik pengumpulan data yang digunakan dalam penelitian ini yaitu kuesioner yang dikirimkan peneliti secara langsung kepada responden yaitu pejabat didinas dan badan pada SKPD Kabupaten Bantul. Data yang dianalisis dalam penelitian ini secara langsung diperoleh dari 18 dinas dan 4 badan di satuan kerja perangkat daerah Kabupaten Bantul. Kuesioner yang dikirimkan oleh peneliti kepada responden berjumlah 100 kuesioner. Kuesioner yang dapat kembali berjumlah 87 kuesioner. Namun, hanya 80 kuesioner yang dapat diolah datanya.

\section{Uji Kualitas Instrumen dan Data}

\section{Uji Validitas}


Berdasarkan hasil uji validitas variabel senjangan anggaran memiliki nilai KMO 0,770>0,5 dan nilai loading factor $>0$,3. Variabel partisipasi anggaran memiliki nilai KMO 0,773>0,5 dan nilai loading factor $>0,3$. Variabel kejelasan sasaran anggaran memiliki nilai KMO 0,603>0,5 dan loading factor $>0,3$. Variabel budaya organisasi memiliki nilai KMO 0,691>0,5 dan loading factor $>0,3$. Variabel reputasi memiliki nilai KMO 0,838>0,5 dan loading factor $>0,3$. Variabel etika memiliki nilai KMO 0,635>0,5 dan loading factor $>0,3$.

\section{Uji Realiabilitas}

Berdasarkan hasil uji reliabilitas variabel partisipasi anggaran, kejelasan sasaran anggaran, budaya organisasi, reputasi, etika dan senjangan anggaran memiliki instrument penelitian yang reliabel karena masing-masing memiliki nilai Cronbach's Alpha (0,745; 0,545; 0,619; 0,781; 0,606; $0,772)$ memenuhi kriteria yang ditetapkan.

\section{Uji Asumsi Klasik}

\section{Normalitas}

Berdasarkan hasil uji normalitas diperoleh nilai sig sebesar 0,995>0,05 maka data dapat dikatakan memiliki distribusi yang normal.

\section{Multikolinieritas}

Berdasarkan hasil uji multikolinieritas dapat menjelaskan bahwa dalam penelitian ini semua variabel independen tidak mengalami multikolinieritas. Hal ini ditunjukkan masing-masing variabel independen yaitu partisipasi anggaran, kejelasan sasaran anggaran, budaya organisasi, reputasi dan etika memperoleh nilai tolerance $(0,252 ; 0,491 ; 0,618 ; 0,208 ; 0,947)>0,10$ dan nilai VIF $(3,962$; $2,035 ; 1,618 ; 4,803 ; 1,056)<10$.

\section{Heteroskedastisitas}

Berdasarkan hasil uji heteroskedastisitas dinyatakan bahwa heteroskedastisitas tidak terjadi dari masing-masing variabel independen. Hal tersebut dapat dilihat dari masing-masing variabel yaitu partisipasi anggaran, kejelasan sasaran anggaran, budaya organisasi, reputasi dan etika memiliki nilai sig $(0,967 ; 0,121 ; 0,779 ; 0,656 ; 0,487)>0,05$.

\section{Hasil Penelitian (Uji Hipotesis)}

Uji hipotesis dalam penelitian ini menggunakan model analisis regresi berganda. Rumus regresi dari penelitian ini adalah sebagai berikut:

$\mathrm{SA}=\boldsymbol{\alpha}+0,592 \mathrm{PA}+0,218 \mathrm{KSA}+0,175 \mathrm{BO}+0,501 \mathbf{R}-0,089 \mathrm{E}+\mathrm{e}$

\section{Uji nilai t}

Tabel 2 Hasil Perhitungan Regresi Berganda

\begin{tabular}{lllll}
\hline \multicolumn{1}{c}{ Variabel } & Koefisien Regresi & \multicolumn{1}{c}{ T } & \multicolumn{1}{c}{ Sig } & \multicolumn{1}{c}{ Keterangan } \\
\hline Konstanta & 10,635 & 1,905 & 0,061 & \\
PA & 0,592 & 4,165 & 0,000 & Signifikan \\
KSA & 0,218 & 2,078 & 0,041 & Signifikan \\
BO & 0,175 & 1,742 & 0,086 & Tidak Signifikan \\
R & 0,501 & 2,831 & 0,006 & Signifikan \\
E & $-0,089$ & $-0,908$ & 0,367 & Tidak Signifikan \\
\hline
\end{tabular}

Sumber: Data primer diolah, 2017 
Hasil dari pengujian dapat dilihat bahwa variabel Partisipasi Anggaran (PA) memiliki nilai sig 0,000<0,05 dan koefisien beta positif 0,592, Kejelasan Sasaran Anggaran (KSA) memiliki nilai sig $0,041<0,05$ dan koefisien beta positif 0,218 serta reputasi $(\mathrm{R})$ memiliki nilai sig $0,006<0,05$ dan koefisien beta positif 0,501 maka dikatakan variabel partisipasi anggaran, kejelasan sasaran anggaran dan reputasi berpengaruh signifikan positif pada senjangan anggaran. Sedangkan variabel Budaya Organisasi (BO) memiliki nilai sig 0,086>0,05 dan koefisien beta positif 0,175 serta Etika (E) memiliki nilai sig 0,367>0,05 dan koefisien beta negatif -0,089 maka dikatakan bahwa budaya organisasi dan etika tidak berpengaruh pada senjangan anggaran.

\section{a. Uji nilai $\mathbf{F}$}

Berdasarkan pengujian yang dilakukan maka diperoleh nilai $\mathrm{F}$ sebesar 63,160 dengan tingkat signifikasi $0,000<0,05$. Sehingga, dapat dinyatakan bahwa variabel independen partisipasi anggaran, kejelasan sasaran anggaran, budaya organisasi, reputasi dan etika secara bersamasama mempengaruhi variabel dependen yaitu senjangan anggaran.

\section{b. Uji Koefisien Determinasi}

Berdasarkan pengujian yang dilakukan maka diperoleh dapat diketahui nilai Adjusted $R$ Square 0,797. Artinya 79,7\% variasi senjangan anggaran dapat dijelaskan oleh perubahan 5 variabel independen, yaitu variabel partisipasi anggaran, kejelasan sasaran anggaran, budaya organisasi, reputasi dan etika. Sedangkan sisanya 20,3\% dijelaskan oleh variabel-variabel independen lain yang tidak ikutserta dalam model penelitian ini.

\section{Partisipasi Anggaran pada Senjangan Anggaran}

Hasil pengujian $\mathrm{H}_{1}$ menunjukkan partisipasi anggaran memiliki nilai koefisien sebesar $0,000<0,05$ dan koefisien beta 0,592 (positif). Maka $\mathbf{H}_{1}$ diterima. Hasil penelitian mengenai partisipasi anggaran berpengaruh positif terhadap senjangan anggaran di satuan kerja perangkat daerah Kabupaten Bantul menunjukkan bahwa dalam penyusunan anggaran pemerintah daerah memberikan banyak kesempatan kepada bawahan untuk ikut serta berpartisipasi dalam proses penyusunan anggaran daerah.

Penelitian ini sejalan dengan penelitian yang dilakukan Putri dan Pradnyantha (2014) menunjukkan bahwa partisipasi anggaran berpengaruh signifikan positif terhadap senjangan anggaran pada SKPD Pemerintahan Kota Denpasar.

\section{Kejelasan Sasaran Anggaran pada Senjangan Anggaran}

Hasil pengujian $\mathrm{H}_{2}$ menunjukkan kejelasan sasaran anggaran memiliki nilai koefisien sebesar $0,041<0,05$ dan koefisien beta 0,218 (positif). Maka $\mathbf{H}_{2}$ ditolak. Jelasnya sasaran anggaran maka membuat para penyusun anggaran merasa takut sasaran yang telah ditetapkan tidak tercapai sehingga mempengaruhi produktifitas kinerja para penyusun anggaran sehingga melakukan senjangan anggaran.

Penelitian ini sejalan dengan penelitian yang dilakukan oleh Biantara dan Putri (2014) yang memperoleh hasil bahwa kejelasan sasaran anggaran berpengaruh signifikan positif terhadap senjangan anggaran disatuan kerja perangkat daerah Kabupaten Badung.

\section{Budaya Organisasi pada Senjangan Anggaran}

Hasil pengujian $\mathrm{H}_{3}$ menunjukkan bahwa budaya organisasi memiliki nilai koefisien sebesar 0,086>0,05 dan koefisien beta 0,175 (positif). Maka $\mathbf{H}_{3}$ ditolak. Budaya organisasi yang rendah dalam penyusunan anggaran maka akan membuat anggota organisasi tidak disiplin terhadap 
peraturan yang ada sehingga akan menyusun anggaran tidak dengan benar dan peraturan yang telah ditetapkan.

Penelitian ini sejalan dengan penelitian yang dilakukan oleh Sugiwardani (2013) menujukkan budaya organisasi tidak berpengaruh terhadap senjangan anggaran pada satuan kerja perangkat daerah Pemerintahan Kota Kediri.

\section{Reputasi pada Senjangan Anggaran}

Hasil pengujian $\mathrm{H}_{4}$ menunjukkan bahwa reputasi memiliki nilai koefisien sebesar 0,006<0,05 dan koefisien beta 0,501 (positif). Maka $\mathbf{H}_{4}$ diterima. Bawahan yang perduli terhadap nama baiknya akan selalu menjaga kinerjanya dalam mencapai target anggaran yang telah ditetapkan sehingga bawahan menyusun anggaran mudah untuk dicapai yaitu dengan melakukan senjangan anggaran agar dapat menghindari hal-hal yang dapat merusak karirnya.

Penelitian ini sejalan dengan penelitian yang dilakukan oleh Putri dan Pradnyantha (2014) bahwa reputasi berpengaruh signifikan positif terhadap senjangan anggaran pada satuan kerja perangkat daerah Pemerintahan Kota Denpasar.

\section{Etika pada Senjangan Anggaran}

Hasil pengujian $\mathrm{H}_{5}$ menunjukkan bahwa etika memiliki nilai koefisien sebesar 0,367>0,05 dan koefisien beta -0,089 (negatif). Maka $\mathbf{H}_{5}$ ditolak. Bawahan yang memiliki etika kurang baik akan memandang bahwa tugas yang diberikan kepadanya kurang mempunyai tanggungjawab moral khususnya kepada masyarakat dan Negara, sehingga mudah untuk melakukan penyimpangan anggaran.

Penelitian ini sejalan dengan penelitian yang dilakukan oleh Biantara dan Putri (2014) menunjukkan bahwa etika tidak berpengaruh terhadap senjangan anggaran pada satuan kerja perangkat daerah Kabupaten Badung.

\section{KETERBATASAN PENELITIAN}

Adapun keterbatasan yang dimiliki oleh peneliti, yaitu objek penelitian dalam penelitian ini hanya terfokus pada pegawai SKPD Kabupaten Bantul, sehingga hasil penelitian ini hanya dapat digunakan pada daerah yang bersangkutan. Dalam penelitian ini tidak terdapat variabel perantara, sehingga hasil penelitian kurang luas. Dalam penelitian ini teknik pengumpulan data hanya menggunakan kuesioner, sehingga hasil penelitiannya bergantung pada kualitas dari kuesioner.

\section{KESIMPULAN}

Berdasarkan hasil penelitian menunjukkan partisipasi anggaran, kejelasan sasaran anggaran dan reputasi berpengaruh signifikan positif terhadap senjangan anggaran. Sedangkan budaya organisasi dan etika tidak berpengaruh terhadap senjangan anggaran.

Adapun saran yang dapat diberikan adalah pertama, penelitian ini hanya mengambil sampel dari beberapa pegawai di SKPD Kabupaten Bantul. Peneliti selanjutnya diharapkan dapat memperluas pengambilan sampel sehingga dapat mewakili populasi yang luas. Kedua, penelitian ini hanya menggunakan kuesioner untuk dalam mengambil data. Peneliti selanjutnya sebaiknya menambah teknik wawancara secara langsung sehingga hasil penelitian akan lebih sempurna. Ketiga, penelitian ini hanya memakai 5 variabel independen, diharapkan untuk peneliti selanjutnya dapat menambahkan variabel moderasi maupun intervening. 


\section{DAFTAR PUSTAKA}

Biantara, A.A Adi \& Putri, I.G.A.M Asri Dwija. (2014). Pengaruh Kejelasan Sasaran Anggaran, Etika, dan Kepercayaan Diri pada Senjangan Anggaran. E-Jurnal Akuntansi Universitas Udayana, 9(2), 385- 391

Cika, M.A.G, \& Asri, D. (2016). Pengaruh kejelasan sasaran anggaran, karakter personal, dan information asymmetry pada senjangan anggaran. Jurnal akuntansi universitas udayana. 14(3). Hlm. 1555-1583.

Ghozali, I., (2011). Aplikasi Analisis Multivariate dengan Program SPSS 19. edisi ke lima, Badan Penerbit Universitas Diponegoro, Semarang.

Halim, A. D. (2009). Pengaruh Budaya Organisasi Terhadap Kinerja Pegawai (Studi Pada Dinas Informasi Komunikasi dan Pengolahan Data Elektronik Kota Medan), Universitas Sumatera Utara

Harvey, M. E. (2015). The effect of employee ethical ideology on organizational budget slack: An empirical examination and practical discussion. Journal of Business \& Economics Research (Online), 13(1)

Karsam. (2013). The Influence of Participation in Budgeting on Budgetary Slack with Information Asymetry as a Moderating Variable and Its Impact on the Managerial Performance (A Study on Yayasan Pendidikan dan Koperasi in the Province of Banten, Indonesia). International Journal of Applied Finance and Business Studies. 1(I), 28-38.

Miyati. (2014). Pengaruh Partisipasi Anggaran Terhadap Budgetary Slack Dengan Pertimbangan Etika Sebagai Variabel Moderasi (Studi Empiris Pada Satuan Kerja Perangkat Daerah Kulon Progo). Skripsi. Universitas Negri Yogyakarta.

Nazzaruddin, I. \& Basuki, A. T. (2015). Analisis Statistika dengan SPSS. Penerbit Danisa Media. Yogyakarta.

Nosihana, A., \& Yaya, R. (2016). Internet Financial Reporting dan Faktor-Faktor yang mempengaruhinya pada Pemerintahan Kota dan Kabupaten di Indonesia. Jurnal Dinamika Akuntansi dan Bisnis. 3 (2), 87-101.

Putri, I.G.A.A., \& Pradnyantha, W. I. (2014). Pengaruh partisipasi anggaran, reputasi, dan etika pada kesenjangan anggaran pada SKPD di Pemerintahan Kota Denpasar, Jurnal Akuntansi Universitas Udayana, 9(1), 133-142

Republik Indonesia. 2004. Undang-Undang No. 32. Pemerintah Daerah.

Republik Indonesia. 2005. Peraturan Pemerintah No. 58. Pengelolaan Keuangan Daerah.

Republik Indonesia. 2007. Peraturan Menteri Dalam Negri No. 59. Pedoman Pengelolaan Keuangan Daerah Penganggaran.

Sugiwardani \& Resti. (2012). AnalisisPengaruh Partisipasi Anggaran Informasi Simetris, Budaya dan Komitmen Organisasi terhadap Budgetary Slack, Jurnal bisnis dan Akuntansi, Fakultas Ekonomi Perbanas Surabaya. 